\title{
Chrząstowska i stereotypy, czyli o reformie kształcenia literackiego, programach i podręcznikach
}

\author{
Bożena Chrząstowska and stereotypes, \\ or: of reforming literary education, of curricula \\ and schoolbooks
}

\author{
Seweryna Wysłouch \\ Uniwersytet im. Adama Mickiewicza w Poznaniu \\ IORCID: 0000-0001-5557-5299
}

\begin{abstract}
The paper presents Professor Bożena Chrząstowska's (1929-2020) hard scientific path as well as her combative nature which proved itself in her battle against school stereotypes. Bożena Chrząstowska insisted that at school, the status of literary work and its interpretation based in literary theory should be enhanced. She perceived a literary work within the broader context of the whole didactic process which aims at preparing students to participate in culture. According to Bożena Chrząstowska, this needs reforming literary education (abandoning literary history in favour of interpretation), rethinking the curricula, and introducing new concepts of schoolbooks.
\end{abstract}

Key words: Bożena Chrząstowska, literary education, curriculum, schoolbook

Streszczenie: Artykuł przedstawia trudną drogę naukową Bożeny Chrząstowskiej (1929-2020) i jej bojową naturę w zwalczaniu szkolnych stereotypów. Chrząstowska walczyła o rangę dzieła literackiego i rolę literaturoznawczej interpretacji w szkole. Dzieło widziała w kontekście całego procesu dydaktycznego, którego celem jest przygotowanie ucznia do uczestnictwa w kulturze. Wymaga to według Niej reformy kształcenia literackiego (rezygnacji z historii literatury na rzecz interpretacji), zmiany koncepcji programów nauczania i nowej formuły podręczników szkolnych.

Słowa kluczowe: Bożena Chrząstowska, kształcenie literackie, program nauczania, podręcznik szkolny

Działalność Bożeny Chrząstowskiej (1929-2020) to pełne pasji łamanie wszelkich stereotypów. Szła przez życie jak burza i jej poczynania przeczyły utrwalonym społecznie schematom: doświadczonego nauczyciela-tradycjonalisty, siedzącego przy biurku naukowca czy młodego zapaleńca - buntownika i reformatora. Obserwowałam Ją z bliska i byłam pełna podziwu dla Jej inteligencji, energii i odwagi.

Wiadomo, że po kilkunastu latach pracy człowiek przyzwyczaja się do warunków, wpada w rutynę, boi się zmian. Tymczasem Chrząstowska przepracowała w oświacie 17 lat: była bibliotekarką, nauczycielką i instruktorką 
w Ośrodku Metodycznym. Zdobyła szacunek nauczycieli, uznanie władz oświatowych i zamiast się wygodnie urządzić na jakimś kuratoryjnym stołku, w wieku 40 lat rzuciła wszystko i zaczęła życie zawodowe od nowa, od skromnego etatu starszego asystenta w Wyższym Studium Nauczycielskim w Poznaniu (1970). Prestiż żaden, pensja słaba, za to obowiązek doktoryzowania się pod groźbą rotacji. Decyzja szaleńcza, zważywszy, że miała rodzinę, dwójkę małych dzieci i rozliczne domowe kłopoty na głowie.

„Nauczycielski bagaż” nie pomagał w karierze naukowej, wręcz przeciwnie. Wprawdzie Chrząstowska miała wykrystalizowane zainteresowania: chciała napisać pracę opartą na szkolnej empirii, badać funkcję pojęć teoretycznoliterackich na lekcjach języka polskiego, ale musiała znaleźć promotora, który by taki temat przyjął, oraz placówkę naukową, która otworzyłaby przewód doktorski. Ani jedno, ani drugie nie było łatwe. W Poznaniu życzliwy historyk literatury nie chciał (czy nie mógł) zaakceptować takiego tematu, a teoretyk - nie widział w nim naukowego problemu. Ratunek przyszedł z Instytutu Badań Literackich w Warszawie, jednak nie od razu. Do tematu przekonał się prof. Kazimierz Bartoszyński, ale na Radzie Naukowej IBL-u dyrektor Kazimierz Wyka powiedział „Nauczycielka? Nic nie zrobi". I wniosek o otwarcie przewodu w głosowaniu przepadł. Udało się go promotorowi „przepchnąć” dopiero za drugim razem (Chrząstowska, Ciechanowska-Barnuś 2015, 15). Bo w świadomości powszechnej pracę naukową należy zaczynać za młodu. Ktoś, kto zaczyna ją późno, na szczęśliwy finał nie ma szans, a szczególnie nie ma szans nauczyciel, podejmujący badania po kilkunastoletniej harówce „przy tablicy”. I oto Bożena Chrząstowska ten stereotyp przełamała. Pracę doktorską Teoria literatury w szkole. Z badań nad recepcja liryki obroniła z sukcesem w IBL-u w 1975 roku i wydała ją drukiem w 1979.

Lata pracy nad doktoratem nie były łatwe. Opracowanie ankiet, które zawierały odpowiednio dobrane wiersze do uczniowskiej interpretacji, uciążliwe zbieranie materiału (lekcje i ankiety przeprowadzane w różnych szkołach), analiza danych, wreszcie pisanie rozprawy - wszystko wymagało czasu, cierpliwości i ustawicznego samokształcenia. Rezygnacji z odpoczynku i rodzinnych wakacji. A jednak Chrząstowskiej udało się doktorat sfinalizować w ciągu 5 lat, przed ustawowym 8-letnim terminem - pomimo rozlicznych obowiązków domowych i dydaktyki uniwersyteckiej, w wieku, kiedy adepci nauki myślą już o profesurze. A kiedy jej następna książka Lektura i poetyka. Zarys problematyki kształtowania pojęć literackich w szkole podstawowej (1987) została uznana za pracę habilitacyjną, usłyszała od prof. Jarosława Maciejewskiego, z którym była zaprzyjaźniona: „Ale po co Ci ta habilitacja? Już za późno. Nic już nie zrobisz..." (Chrząstowska, Ciechanowska-Barnuś 2015, 16). Bo doktorat był warunkiem pozostania na uczelni, a dalsze stopnie - to $\mathrm{w}$ powszechnej świadomości szczeble w karierze dla ludzi młodych, a nie dla emerytów. I ten stereotyp został też szczęśliwie przełamany. Habilitacja, a wkrótce profesura (1992) pozwoliły

\section{Polonistyka. Innowacje}

Numer 14, 2021 
energicznej i pełnej zapału pani Profesor działać skutecznie na forum ogólnopolskim, pełnić rozliczne funkcje, kształcić mądrych dydaktyków, no i reformować szkołę.

Kim jest reformator? W świadomości społecznej to idealista, młody entuzjasta, który nie chce się godzić na świat zastany, buntuje się, żąda zmian natychmiast i wierzy, że są one możliwe. Nie liczy się z przeciwnościami, z oporem społecznym, nie wie, co ryzykuje. I najczęściej dostaje po głowie. Ten stereotyp młodego zapaleńca Chrząstowska skutecznie przełamała. A raczej przełamywała w całej swojej dojrzałej działalności zawodowej. Reformowała szkołę na dwa sposoby: swoją indywidualną „pracą u podstaw" - poprzez publikacje i kształcenie nauczycieli, oraz przez tworzenie form społecznego nacisku na władze oświatowe - organizowanie społecznych komisji, które pod Jej kierunkiem opracowały nowe programy i nowoczesną koncepcję nauczania. Jeśli spojrzeć z czasowego dystansu na naukową i reformatorską działalność Chrząstowskiej, to przede wszystkim uderza nieustanne poszerzanie perspektywy w myśleniu o szkole i nad wyraz konsekwentne pogłębianie podjętej problematyki. I tym właśnie aspektem chciałabym się tu zająć ${ }^{1}$.

\section{Tekst literacki}

Od tego wszystko się zaczęło. Pracując w Ośrodku Metodycznym (19631970), Chrząstowska hospitowała niezliczone lekcje polskiego i widziała, że tekst literacki pełni na nich podrzędną rolę, najczęściej traktowany jest jako dokument biograficzny lub ilustracja stosunków polityczno-ekonomicznych. Nie było w tym nic dziwnego: wszak kadra nauczycielska kształcona była w latach 50. (ona sama skończyła studia w roku 1952!). A lata 60. to okres żywego ruchu intelektualnego na uczelniach i nadrabiania zaległości. Nauki humanistyczne w Polsce przeżywały wówczas swoisty „przełom antypozytywistyczny". Na UJ wrócił Roman Ingarden, przypomniano Praską Szkołę Strukturalną, ożywiły się kontakty z Romanem Jakobsonem, który przyjeżdżał do Polski kilka razy. Rosło poczucie swoistości dyscypliny i ranga teorii (Głowiński, Wołowiec 2018, 193-207). Strukturalistyczne inspiracje płynęły także z Rosji (Łotman) i Francji (Barthes). W takich warunkach bujnie rozwijała się teoria literatury, a ośrodkami wiodącymi był wówczas warszawski IBL i UAM. Pozostać na to wszystko obojętnym - to nie w stylu Chrząstowskiej. Starała się ze wszystkich sił walczyć z zapóźnieniami szkoły. Organizowała konferencje metodyczne, które miały na celu prezentowanie nowych trendów w nauce i walczyła o rangę tekstu literackiego. Efektem tej walki, samokształcenia oraz refleksji nad szkołą i jej potrzebami, był wykrystalizowany temat pracy doktorskiej i - asystentura w Wyższym Studium Nauczycielskim. Pracowałyśmy tam razem.

${ }^{1}$ Pomijam inne dziedziny Jej działalności: studia o literaturze (Poezje Czesława Miłosza, 1982, 1993; Otwarte niebo. Literackie świadectwa przeżywania Eucharystii, 1992); wieloletnie redagowanie „Polonistyki” (1992-2014) czy kierowanie polskim oddziałem Guardini Stiftung. 
Program kładł nacisk na analizę literacką, kształcenie sprawności, pracę z tekstem. My miałyśmy jeszcze jeden cel dodatkowy: uczenie literatury współczesnej, ponieważ w szkole literatura kończyła się na II wojnie światowej. Na późniejszą nie starczało nauczycielom czasu ani ochoty, bo często byli wobec niej bezradni.

Szczególnie liryka po 1956 roku miała opinię trudnej i niezrozumiałej. W latach 70. nie było antologii, nie było wznowień, nie było Internetu, nie było kserokopiarek. Były jedynie wysłużone maszyny do pisania, do których trudno było zdobyć taśmę i papier, i na których można było wystukać najwyżej 7 kopii. Toteż z zapałem przepisywałyśmy po kilka razy wiersze i fragmenty prozy, żeby każdy student miał tekst przed nosem, żeby nie mówił ponad i poza tekstem. Analizy strukturalnej uczyłyśmy z entuzjazmem, ponieważ pozwalała łączyć naukę o literaturze z nauką o języku i wprowadzać w arkana poezji lingwistycznej. Tak zrodził się pomysł, by zrobić tom ćwiczeń do podstawowego podręcznika - Zarysu teorii literatury „Trojaczków”: Michała Głowińskiego, Aleksandry Okopień-Sławińskiej i Janusza Sławińskiego (1962). Tom ćwiczeń nie powstał, powstały za to kierowane do szkoły Wiadomości $z$ teorii literatury $w$ analizie literackiej (1974), przerobione później na Poetykę stosowana (1978, 1987, 2000). Książka rzeczywiście trafiła do szkoły, funkcjonowała wśród nauczycieli i olimpijczyków, a Bożena stała się prelegentką rozrywaną na nauczycielskich konferencjach, bo jej wystąpienia nigdy nie były nudne. $\mathrm{Z}$ temperamentem walczyła o nowe spojrzenie na przedmiot nauczania, o kształcenie literackie w szkole. Doskonale jej cechy uchwycił dziekan Wydziału, prof. Bogdan Walczak w jubileuszowym wierszyku (1999):

Uczy, krzewi, edukuje,

Tworzy, pisze, publikuje.

Świeci, kształci, wychowuje,

Plewi, tępi, reformuje.

Gromi, działa, redaguje,

Głosi, szerzy, dyskutuje.

Bez wytchnienia, bez znużenia,

Bez wahania, bez zwątpienia.

(Chrząstowska, Ciechanowska-Barnuś 2015, 100)

Walka o rangę tekstu literackiego w szkole i rolę literaturoznawczej interpretacji, która przygotowuje uczniów do samodzielnego odbioru literatury, była pierwszym krokiem na drodze badawczej i - jak się okazało - otworzyła przed adeptką szereg nowych problemów.

\section{Wiedza teoretyczna a interpretacja}

Przede wszystkim Chrząstowska, inspirowana współczesną teorią komunikacji, widziała tekst literacki w szerokiej perspektywie, potraktowała go 
jako jeden (ale nie jedyny!) element toku kształcenia, którego celem naczelnym jest świadomy odbiór literatury i przygotowanie ucznia do uczestnictwa w kulturze. Dlatego punktem wyjścia była dla Niej refleksja nad całym procesem dydaktycznym, uwzględnienie skomplikowanej problematyki szkolnego odbioru literatury, który przedstawiała jako proces dwustopniowy, ponieważ „zwykła” relacja autor - czytelnik jest w szkole zapośredniczona przez działania nauczyciela. On organizuje pracę i stwarza na lekcji sytuację problemową, on wyznacza rolę dla ucznia. Toteż w referacie Autor - dzieło - poetyka. Problemy interpretacji w szkole (1979) uwzględniony został nie tylko sam „autonomiczny” tekst, lecz wszystkie trzy podstawowe elementy procesu dydaktycznego: nauczyciel - dzieło literackie -uczeń (Chrząstowska 2009, 67-87). Skomplikowany układ relacji komunikacyjnych powoduje, że kształcenie literackie jest wielostronnie uwarunkowane i w zależności od zespołu uczniowskiego, sytuacji, rozmaitych okoliczności - winno być zróżnicowane metodycznie. Oczywiście ranga dzieła literackiego jest tu nie do przecenienia, ponieważ stawia ucznia wobec nowego problemu, zmusza do wysuwania i weryfikowania hipotez, a zatem pozwala go aktywizować. Rośnie tym samym rola interpretacji, pojmowanej jako kierowany przez nauczyciela proces badawczy, który poszerza wiedzę i uczy umiejętności odbioru literatury. A tu dochodzi problem literaturoznawczego instrumentarium. Czy jest potrzebne? A jeżeli się je wprowadza, to jaką powinno pełnić funkcję?

$\mathrm{Na}$ zasadnicze pytanie o rolę pojęć teoretycznych w kształceniu kompetencji literackich, odpowiedziała praca doktorska Teoria literatury $w$ szkole. $Z$ badań nad recepcja liryki, uzasadniając rzetelnie ich przydatność. Chciałabym tu podkreślić nieortodoksyjną postawę Autorki, która akcentowała, że edukacja teoretyczna nauczyciela jest ważniejsza niż edukacja teoretyczna ucznia (Chrząstowska 2009, 85, 15), że - jednym słowem - szczegółowa wiedza teoretyczna jest wtórna wobec procesu interpretacji. Poza tym preferowana ze względu na korzyści dydaktyczne analiza strukturalna nie przesłoniła Autorce innych sposobów pracy z tekstem, czego najlepszym dowodem zredagowany przez Nią numer „Polonistyki” $O$ czytaniu („Polonistyka” 1992, nr 5) poświęcony różnym typom interpretacji (Chrząstowska (red.) 1995, 104-125) ${ }^{2}$.

Chrząstowska badania empiryczne przeprowadziła w szkołach średnich. Ale zaczęło ją nurtować pytanie: jak ta problematyka wygląda szczebel niżej, w szkole podstawowej? Jak kształtuje się myślenie abstrakcyjne dziecka? Kiedy i jakie pojęcia teoretycznoliterackie można wprowadzać w edukacji, zgodnie $\mathrm{z}$ wiekiem młodego odbiorcy i prawami jego percepcji? Tym właśnie zagadnieniom poświęcona została książka Lektura i poetyka. Zarys problematyki kształtowania pojęć literackich $w$ szkole podstawowej (1987) oraz artykuły z 1989 roku O rozumieniu utworów literackich

${ }^{2}$ O Chrząstowskiej - redaktorce naczelnej „Polonistyki” i stworzonym przez nią autorskim modelu pisma, które redagowała ponad 20 lat (1992-2014), pisałam osobno (Wysłouch 2018). 
(przez dzieci młodzież) czy Przekład wiedzy o literaturze na język dziecka (Chrząstowska 2009). W podręczniku akademickim z metodyki Innowacje i metody protestowała przeciwko „fetyszowi terminologii” (Kwiatkowska-Ratajczak (red.) 2011, 272-273). Podkreślała, że należy zaczynać edukację od pojęć ogólnych i wprowadzać takie terminy, które nie tylko nazywają zjawiska, ale pełnią funkcję operacyjną, służą interpretacji. Badania i przemyślenia doprowadziły Ją do zbudowania konsekwentnej siatki pojęć teoretycznych, która stanowi fundament kształcenia polonistycznego w całym toku nauczania: od szkoły podstawowej aż do matury. Siatka ta została uwzględniona w opracowanej pod Jej kierunkiem i zaaprobowanej przez Zjazd Polonistów Podstawie programowej języka polskiego (1995).

\section{Zamiast historii literatury - analiza i interpretacja}

Badanie szkolnej empirii uświadomiło z całą ostrością problem historii literatury w szkole. Metodycy byli zasadniczo zgodni, że historia literatury jako nauka szczegółowa jest nie do realizacji na lekcjach języka polskiego, staje się uproszczonym rejestrem gromadzonych w pamięci faktów, o których i tak się szybko zapomina. Jednym słowem należy ją zastąpić poznawaniem kanonu, czytaniem utworów literackich. Takie sugestie formułował Michał Głowiński na podstawie swoich wieloletnich doświadczeń egzaminacyjnych podczas olimpiad polonistycznych:

przedmiotem nauczania literatury w szkole nie powinny być literackie procesy historyczne, ale dzieła i związane z nimi podstawowe style. A więc mówimy o Dziadach czy Beniowskim nie po to, by powiedzieć coś ogólnego o romantyzmie; zajmujemy się romantyzmem z tej racji, że chcemy lepiej zrozumieć Dziady czy Beniowskiego. Mówiąc inaczej: w szkole obowiązywać winien nie porządek historii, lecz porządek interpretacji (Głowiński 1997, 107).

A zatem historię literatury powinna zastąpić analiza i interpretacja utworów literackich. Nie jest to tylko zmiana polegająca na redukcji encyklopedyzmu, porzuceniu „schematycznej i naiwnej faktografii”, ale diametralnie inne podejście do dzieła. Wyeksponowane zostają nie cechy reprezentatywne dla okresu czy prądu literackiego, ale to, co indywidualne i aktualne, bliskie młodemu odbiorcy. To dzieło swoim kształtem przywołuje tradycję literacką. Idziemy więc od dzieła - ku tradycji, a nie odwrotnie: od charakterystyki epok - do dzieła. Stąd dobitna i obrazoburcza teza Chrząstowskiej sformułowana w artykule Jak uczyć rozumienia historyczności w nowym liceum (2006):

trzeba zerwać z tradycją nauczania historii literatury w liceum, by móc - obok innych zadań - efektywnie rozwijać świadomość historyczności dzieł literackich, języka i innych tekstów kultury w szkole (Chrząstowska 2009, 163).

Jednym słowem należy uczyć obcowania z tradycją poprzez interpretację dzieł literackich. Ta teza miała daleko idące konsekwencje. Przede 
wszystkim wymuszała rezygnację z chronologicznie ułożonego materiału na rzecz układu problemowego, który pozwala na różnorodne porządkowanie literackiej materii: według wartości, zagadnień egzystencjalnych czy gatunków literackich. Z kolei układy spiralne (lub koncentryczne) umożliwiają powroty i powtórki tego, co ważne. Ponadto rezygnacja z toku historycznoliterackiego zwalnia nauczyciela od omawiania na początku edukacji epok odległych, szczególnie trudnych dla ucznia. O walorach problemowego układu Chrząstowska szczegółowo pisała w podręczniku Innowacje i metody, w rozdziale pod tytułem Funkcja wiedzy historycznoliterackiej w liceum (Kwiatkowska-Ratajczak (red.) 2011, 281-296).

\section{Reforma kształcenia polonistycznego}

Rozprawiwszy się z tekstem, interpretacją, teorią i historią literatury na różnych szczeblach edukacji, Chrząstowska zajęła się programami nauczania. Reforma programów zainicjowana została przez ministerstwo w połowie lat 70., w związku z reformą szkoły (zamiast 7-letniej szkoły powszechnej wprowadzono wówczas 10-latkę). Miała ona kilka faz, które szczegółowo Autorka opisała (Chrząstowska, Ciechanowska-Barnuś 2015, 228-244). Dla nas interesująca jest przede wszystkim „oddolna” rewolucja programowa, którą Chrząstowska zainicjowała w okresie Solidarności i kontynuowała w latach 90., tworząc ogólnopolski zespół, pracujący społecznie, do którego włączyli się wybitni literaturoznawcy i który opracował dokumenty zyskujące aprobatę najważniejszych gremiów polonistycznych: Towarzystwa Literackiego im. Adama Mickiewicza, Komitetu Nauk o Literaturze PAN i Zjazdu Polonistów w 1995 roku. Prace nad reformą nauczania trwały 5 lat (1991-1996) i były szeroko zakrojone. Po doświadczeniach PRL-owskich, kiedy obowiązywał jeden zatwierdzany przez ministerstwo, zideologizowany program nauczania, za wzorem państw europejskich (szczególnie Francji), w ogniu dyskusji wypracowano nową koncepcję kształcenia literackiego. Chrząstowska była spiritus movens tego ruchu. Nawiązała ścisłe kontakty z ośrodkami metodycznymi innych uczelni, szczególnie z ówczesną Wyższą Szkołę Pedagogiczną w Krakowie (obecnie Uniwersytet Pedagogiczny) i Uniwersytetem Wrocławskim. Zorganizowała na temat reformy trzy ogólnopolskie konferencje naukowe, opublikowała szereg artykułów i w efekcie opracowała 8 dokumentów programowych. Zaangażowała się bez reszty. A jak to odbiło się na najbliższych, wspomina córka, Joanna Ciechanowska-Barnuś:

A w tle były REFORMY.

Głównie kolejne reformy edukacji, w które Mama angażowała się bez umiaru, powodując tym samym głęboki uszczerbek w życiu emocjonalnym swoich dzieci, ich absolutne uspołecznienie oraz prawie całkowite udomowienie Męża. A myśmy to znosili i szybko nauczyliśmy się świetnie dawać sobie radę. Spoglądając wstecz, mam wrażenie, że REFORMY prześladowały nas bardziej niż innych ludzi z naszego 
otoczenia. Do zaangażowania Mamy w sprawy edukacji i kolejnych reform, którym zapamiętale służyła, i wynikającej z tego nieobecności przyzwyczaiłam się szybko, jak Eskimos do zimna lub mieszkaniec Afryki do upału. To doświadczenie lat dziecinnych pozwoliło z wdziękiem i wprawą w wieku dojrzałym stawić czoło, znieść ataki i skutki kolejnych REFORM - społecznych, obyczajowych, finansowych, ekonomicznych. I myli się ten, kto myśli, że jeśli w kraju nie było od 70 lat wojny, to pokolenia żyją w ciszy i spokoju. Może inni. U nas zawsze zakręty i zawirowania. I zawsze z REFORMAMI w tle. Chyba nikt się tyle nie nagadał i nie nasłuchał o REFORMACH, ile członkowie i przyjaciele naszej rodziny (Chrząstowska, Ciechanowska-Barnuś 2015, 246).

Reforma opracowana przez zespół pod kierunkiem Chrząstowskiej nie dotyczyła szkoły jako instytucji, jej profilu, administrowania oświatą, wzdłużenia czy skrócenia wieloletniego procesu edukacji, ale samego meritum: koncepcji nauczania. Zrezygnowano z tradycyjnego, zatwierdzanego odgórnie i obowiązującego nauczyciela „programu” na rzecz zwięzłej „podstawy programowej", zawierającej tylko obowiązujące minimum, które nauczyciel - według uznania - mógł rozbudować tworząc swój indywidualny program autorski. A zatem reforma wprowadzała - zamiast jednego obowiązującego, ministerialnego programu - wielość programów autorskich, które miały rozbudzić inicjatywę nauczyciela, pozwalały na indywidualizację procesu nauczania i zróżnicowanie metod pracy. Tak pojęta reforma nie wymagała nakładów finansowych. Dotyczyła szeroko pojętego polonistycznego kształcenia, rewolucjonizowała sam proces dydaktyczny, traktując podmiotowo jego „aktorów” - ucznia i nauczyciela. Jej losy są smutne, toteż Autorka uważała lata poświęcone tej sprawie za czas stracony. Zmieniali się ministrowie oświaty, każdy pracę poprzedników wyrzucał do kosza i reformował szkołę po swojemu, a „podstawa programowa”, w wyniku działań coraz to nowych, sowicie opłacanych ministerialnych komisji, puchła i puchła zmieniając się w szczegółowy, obligatoryjny program, niemożliwy do realizacji w rzeczywistości szkolnej, przy ograniczonej (z konieczności) liczbie godzin.

Praca nad programami nauczania oraz refleksja nad procesem dydaktycznym doprowadziła z kolei do zajęcia się tym, co nauczyciel i uczeń powinni mieć pod ręką - podręcznikami do nauki języka polskiego. Przyświecała Chrząstowskiej w teorii i w praktyce idea nowoczesnego podręcznika, który nie jest „gotowcem”, nie wyręcza nauczyciela i nie podsuwa uczniowi „obowiązujących” wszem wobec interpretacji, ale stawia go w sytuacji problemowej. Dlatego Chrząstowska zorganizowała ogólnopolską konferencję poświęconą podręcznikom Podręczniki literatury w szkole średniej. Wczoraj - dziś - jutro (materiały zostały opublikowane pod jej redakcją w 1991 roku) i zainicjowała szeroko zakrojone prace zespołowe nad opracowaniem podręczników dla klas licealnych.

Była zdecydowaną przeciwniczką stereotypowej „narracji podręcznikowej", której autorzy nie tylko omawiali najważniejsze problemy epoki, ale także interpretowali kolejne lektury, zwalniając tym samym nauczyciela

Polonistyka. Innowacje

Numer 14, 2021 
i ucznia od analizy tekstu i samodzielnego odczytywania sensu dzieła. Dlatego próbowała tę narrację ograniczać w podręcznikach, które redagowała. Najpierw nieśmiało w obejmującym pięć epok, obszernym podręczniku dla klasy I liceum Starożytność - oświecenie (1987), opracowanym razem z Marią Adamczyk i Józefem T. Pokrzywniakiem, a przede wszystkim w Literaturze współczesnej. Podręczniku dla maturzystów (1992), którego byłam współautorką, razem z Bożeną Chrząstowską i z Ewą Wiegandtową. Literatura współczesna zrywa z dotychczasowymi standardami i przypomina antologię. Autorska narracja dominuje w zwięzłych, syntetyzujących rozdziałach części I Fakty i problemy, natomiast większość miejsca zajmują utwory zamieszczone w części II Teksty i konteksty. Pytania i polecenia, które mogą pomóc w interpretacji, znajdują się na końcu każdego rozdziału. W ten sposób dedukcyjny charakter tradycyjnej narracji podręcznikowej zostaje zastąpiony tokiem indukcyjnym: obserwacją literackiej empirii, z której uczeń - przy pomocy nauczyciela - może wyciągnąć uogólniające wnioski. Nauczyciel jest tym, kto dokonuje wyboru utworów, kieruje procesem interpretacji i pomaga w budowaniu syntezy, natomiast podręcznik urozmaiconą typografią sygnalizuje to, co ważne. Był to nowy model książki dla ucznia, nastawiony na aktywizację młodego odbiorcy i samodzielny odbiór literatury. Pamiętam niepowtarzalną atmosferę naszej pracy, entuzjazm, i przekonanie, że zrywamy ze szkolną nudą, że dydaktyka może być ciekawa i atrakcyjna, i dla ucznia, i dla nauczyciela. Nie wiedziałyśmy, co nam grozi. Oberwałyśmy nieźle.

Po kolejnej reformie oświaty (to jest wprowadzeniu 3-letniego gimnazjum oraz 3-letniego liceum) Chrząstowska zajęła się podręcznikami opartymi na własnym programie autorskim Ucze się sam... Program nauczania $w$ liceum ogólnokształcacym, profilowanym i technikum. Język polski $w$ zakresie podstawowym i rozszerzonym (2002). Zaplanowała i zredagowała pięciotomowy cykl, pomyślany bardzo ambitnie. Obejmował całość kształcenia w liceum: tom I to zwięzły podręcznik dla ucznia na okres edukacji: Skarbiec języka, literatury, sztuki dla klas I - III (2002)33, prócz niego dla każdej klasy został opracowany tom wypisów z ćwiczeniami. Podtytuły Wypisów orientowały w tematyce i zakresie materiału. Klasa I poświęcona została literaturze współczesnej: Kultura XX wieku i jej tradycje (2002), klasa II - dziewiętnastowiecznej: Kultura XIX wieku i jej tradycje (2003) oraz klasa III staropolszczyźnie: Staropolskie korzenie współczesności $(2004)^{4}$. Nie zapomniano także o nauczycielu, instrukcje dla niego znajdują się w tomie piątym, autorstwa Bożeny Chrząstowskiej, Krzysztofa Koca i Pawła Nowaka (Skarbiec języka, literatury, sztuki. Wskazówki metodyczne, 2004). Przedsięwzięcie było więc szeroko zakrojone i w całości zostało zrealizowane.

3 Współautorzy podręcznika: B. Chrząstowska, J. Fiećko, M. Hendrykowski, B. Judkowiak, B. Kaniewska, A. Legeżyńska, T. Mika, W. Ratajczak, L. Teusz, B. Walczak.

${ }^{4}$ Prócz współautorów tomu I Wypisy opracowali K. Kuczyńska-Koschany i P. Nowak. 
Skarbiec języka, literatury, sztuki wcielił w życie wszystkie idee Chrząstowskiej. Narracja podręcznikowa - podstawowe informacje o prądach i epokach podane $\mathrm{w}$ zgodzie $\mathrm{z}$ chronologią - wyodrębniona została w osobnym tomie i porządkuje materiał. Natomiast poszczególne tomy Wypisów burzą chronologię. Mają układ problemowy i kierują się postulowanym przez Głowińskiego „porządkiem interpretacji”. Punktem wyjścia są utwory, które zostały wyposażone w staranną obudowę dydaktyczną, zamieszczoną w oznakowanych i różniących się kolorem ramkach. Dostarczają one potrzebnych informacji, cytują przywoływane aluzyjnie konteksty, proponują ćwiczenia językowe i literackie. Tym sposobem Skarbiec... stara się zaciekawić literaturą i skłania do samokształcenia. Jest doskonałym podręcznikiem dla ucznia. Cykl został doceniony przez specjalistów i zyskał nagrodę Polskiej Akademii Umiejętności, ale nie przełamał tradycjonalizmu, nauczycielskiej rutyny i nie przeniknął do szkoły. Kolejna reforma oświaty, likwidacja gimnazjów i trzyletniego liceum przypieczętowała jego los. Niemniej stanowi ciekawy, rzec można wzorcowy dokument - nowatorską propozycję, zgodną ze współczesnym literaturoznawstwem, nauką o języku i metodyką nauczania. Dowodzi, że teoretyczne koncepcje zrodzone przy biurku mogą zyskać atrakcyjny kształt praktyczny. Przeciera szlaki, pokazuje drogę kształcenia literackiego w szkole.

\section{Polskie piekło i skóra słonia}

Myliłby się ktoś, kto by sądził, że dynamiczna działalność naukowa i reformatorska Bożeny Chrząstowskiej była li tylko pasmem sukcesów. Oczywiście, Chrząstowska odniosła sukces bez precedensu. Pracowała społecznie, bez pieniędzy, bez zaplecza instytucjonalnego, z gromadką zapaleńców. Mimo to udawała się jej rzecz niezwykła: potrafiła zmieniać świadomość nauczycieli. Ale nie była w stanie zmienić świadomości kulturalnego establishmentu i to, co robiła, bardzo się warszawskim literatom nie podobało.

W 1992 roku „Gazeta Wyborcza” rozesłała złożone w ministerstwie propozycje programowe „do wybitnych pisarzy, krytyków i historyków literatury". Wyniki ankiety ogłosiła w niepodpisanym[!] artykule Czego Jaś nie przeczyta, tego... Wszystkie przytoczone tam wypowiedzi były zdecydowanie negatywne, a zmianami programowymi obciążona została personalnie „pani Chrząstowska”, oskarżana o koniunkturalizm, historyzm, upolitycznienie, ideologizację szkoły, zaściankowość, etc. Ona odpowiada za to, że „pominięcia w dziedzinie lektur obowiązkowych są ogromne, decyzje często nie uzasadnione” (Czego Jaś..., 1992, 8). „Pani Chrząstowska” zaprotestowała, bo opracowała tylko jeden podpisany nazwiskiem program autorski (w roku 1990), a dyskutanci wypowiadali się o pięciu różnych dokumentach (dotyczących szkoły podstawowej i średniej) i wszystkie jej przypisali. 
Sprostowanie wysłało też do „Gazety” Ministerstwo Oświaty ${ }^{5}$. Ale to był tylko wstęp, parę dni później nastąpił w prasie ogólnopolskiej zmasowany atak na Literaturę współczesna. Nowoczesny kształt podręcznika za bardzo odbiegał od szkolnych stereotypów i - co gorsze - stanowił groźną konkurencję dla warszawskiego środowiska.

„Gazeta Wyborcza” i „Życie Warszawy” jednocześnie zamieściły deprecjonujące opinie, później włączyła się prasa regionalna i państwowa telewizja. Jan Walc w tekście o wdzięcznym tytule MEN da dzieciom... Nowy, pełen głupstw i błędów podręcznik literatury współczesnej (Walc 1992), nader sprawnie posłużył się językiem Marca 1968 („,chamska niewiedza majdluje[!] brudnymi paluchami"), wykazał niebywałą inwencję nazewniczą (mówił o nas, autorkach, per „trzy niechluje”), a cały podręcznik to "głupstwa, błędy i niegramatyczności". A ponieważ podręcznika nie czytał, zaraz na wstępie uchylił dyskusję merytoryczną, na którą, według niego, nie zasłużyłyśmy, i czepiał się drobiazgów ${ }^{6}$. Zaatakował także wydawcę i powołanych przez ministerstwo recenzentów, pomówił ich o korupcję, bo najbardziej go bolało, że książka została dopuszczona do szkolnego użytku. W następnym numerze „Życia Warszawy” ten wątek rozwinęła twórczo Izabella Wit-Kossowska, pisząc Dzieje bubla. Czy wart 20 tysięcy złotych? (Wit-Kossowska 1992). W „Gazecie Wyborczej” dołożyła swoje Małgorzata Baranowska, która nazwała książkę czytanką dla zerówki i wołała: „Ludzie! Chrońcie swe dzieci!” (Baranowska 1992). Za nią poszli inni. Krytykowano „zbędną” obudowę dydaktyczną (pytania, tabelki i ćwiczenia dla uczniów), a przede wszystkim redukcję materiału. Obszar na wpół pustynny. „Literatura współczesna” okrojona - taki tytuł w „Polityce” nosiła kuriozalna recenzja Jana Pieszczachowicza, który wymienił ponad 70 nazwisk współczesnych twórców, niesłusznie przez nas pominiętych (Pieszczachowicz 1992). A w telewizji Andrzej Drawicz i Jacek Bocheński przypisali nam bolszewicki stosunek do przeszłości ${ }^{7}$. Warszawskie gazety nie drukowały głosów innych niż napastliwe, lądowały one w redakcyjnych koszach $^{8}$, a autorki i wydawca musieli powoływać się na prawo prasowe i grozić procesem, żeby łaskawie zechciano zamieścić repliki ${ }^{9}$. Inaczej było w Krakowie. „Tygodnik Powszechny” zamieścił artykuł Anny Legeżyńskiej Jaś i Małgosia w rezerwacie, czyli kto się boi "Literatury współczesnej” (Legeżyńska 1992), „Dekada Literacka” i „Arka” zorganizowały dyskusję

\footnotetext{
${ }^{5}$ Artykuł ukazał się w „Gazecie Wyborczej” 23. IX. 1992, s. 8-9; sprostowanie MEN - 5. X, s. 9; protest Chrząstowskiej - w dziale listów do redakcji 2. XI, s. 10.

6 Według redakcyjnych przecieków podręcznik czytała asystentka „Życia Warszawy” i wyłapywała wszelkie potknięcia adiustacyjne, by Walc błysnął polemicznym talentem. I błysnął.

${ }^{7}$ 30.I.1993 w TVP 2 rozmowę prowadził Jerzy Markuszewski. Udział w niej wzięli J. Bocheński, A. Drawicz i A. Kowalczykowa.

${ }^{8}$ Z wyjątkiem artykułu K. Jakowskiej W obronie podręcznika (Jakowska 1992). Odrzucone teksty: T. Patrzałka (Książka na ławkę szkolna) i S. Bortnowskiego (Kto w podręczniku, kto na indeksie) opublikowała „Polonistyka” 1993, nr 5. Tamże fragmenty listów i oświadczeń nauczycieli.

${ }^{9}$ Zob. Manipulacje z podręcznikiem, „Gazeta Wyborcza” 1992, nr 241, s. 11 oraz Zła wola, "Życie Warszawy” 1992, nr 256, s. 8-9. Replika wydawcy O podręczniku „Literatura współczesna”, "Życie Warszawy" 1992, nr 247, s. 9.
} 
z udziałem autorek ${ }^{10}$. Sytuację tak skomentował jeden z naszych kolegów: „żeby to przetrwać, trzeba mieć skórę słonia”. Mimo obelg Walca, rozdzierania szat i publicznie rzuconej anatemy, podręcznik dobrze funkcjonował w szkołach, wyeliminowała go dopiero kolejna reforma oświaty: wprowadzenie gimnazjum i trzyletniego liceum.

\section{Stereotypy trzymają się mocno}

Zdawałoby się, że po trzydziestu latach dawne spory poszły w niepamięć. Społeczeństwo zostało wyedukowane, idee niegdyś nowe stały się oczywistością. Ale nie. Chrząstowska znów znalazła się na tapecie. Tym razem odpowiada za upadek polskiej szkoły. Podnieśli głos bowiem wrogowie strukturalizmu (Lewiński 2004), a także miłośnicy historii literatury, jak Andrzej Waśko, głoszący prymat patriotycznego wychowania (Kwiatkowska-Ratajczak 2021, 12-14). Wracają lata 50., odradza się prymitywna ideologizacja, lekceważąca dorobek współczesnej pedagogiki, psychologii, nie mówiąc już o literaturoznawstwie i metodyce nauczania. Tymczasem właśnie Chrząstowska podkreślała znaczenie aksjologii w edukacji, zalecała czytanie według wartości. W podręczniku Innowacje i metody (rozdział Formacja uczniów) pisała: „polonista wychowuje wyłącznie poprzez kontakt z literaturą, z tekstami kultury, z językiem" (KwiatkowskaRatajczak (red) 2011, 132). „Poprzez” literaturę, a nie - jak żądają ideolodzy - poza literaturą. To, co głosiła, okazało się zbyt radykalne, zbyt odstawało od zakorzenionych społecznie stereotypów.

Było Jej zamiarem opracowanie nowoczesnej metodyki nauczania. Chciała zebrać swoje doświadczenia i uwzględnić dotychczasowy dorobek dyscypliny w teorii i praktyce pedagogicznej. Brak takiej pozycji odczuwali szczególnie studenci kierunków polonistycznych i początkujący nauczyciele. I ten zamiar udało się Jej za życia zrealizować. Stworzyła zespół, który wspólnym wysiłkiem, korzystając z Jej prac i różnorodnych inspiracji, opracował kompleksowy podręcznik metodyki Innowacje i metody. Tom I. W kręgu teorii i praktyki. Podręcznik akademicki dydaktyki kształcenia polonistycznego (pod redakcją Marii Kwiatkowskiej-Ratajczak 2011). Uwzględnione w nim zostały te trzy aspekty procesu dydaktycznego, na które ona kładła szczególny nacisk: uczeń, przedmiot nauczania i proces kształcenia. Im właśnie poświęcone są kolejne części książki. Na karcie tytułowej widnieje napis „Tom I”. Mam nadzieję, że wbrew wszelkim przeciwnościom inicjatywa będzie kontynuowana i wkrótce powstanie „tom II”.

\section{Bibliografia:}

Baranowska Małgorzata, 1992, „Społeczeństwo bawiło się na karuzeli”, „Gazeta Wyborcza”, nr 228, s. 9.

Chrząstowska Bożena (red.), 1995, Kompetencje szkolnego polonisty. Szkice i artykuły $z$ metodyki, Warszawa.

10 „Dekada Literacka” 1993, nr 2; „Arka” 1993, nr 43. 
Chrząstowska Bożena (red.), 1997, Kompetencje szkolnego polonisty 2. Szkice i artykuły $z$ metodyki $z$ lat 1994-1996, Warszawa.

Chrząstowska Bożena, 1987, Lektura i poetyka. Zarys problematyki kształtowania pojęć literackich w szkole podstawowej, Warszawa.

Chrząstowska Bożena, 2009, Przedmiot, podmiot i proces. Szkice z metodyki kształcenia polonistycznego, Kwiatkowska-Ratajczak M., Wantuch W. (wybór i oprac.), Poznań.

Chrząstowska Bożena (red.), 2002, Skarbiec języka, literatury, sztuki dla klas I - III, Poznań.

Chrząstowska Bożena (red.), 2002-2004, Skarbiec języka, literatury, sztuki. Wypisy z ćwiczeniami dla kl. I: Kultura XX wieku i jej tradycje; dla kl. II: Kultura XIX wieku i jej tradycje; dla kl. III: Staropolskie korzenie współczesności, Poznań.

Chrząstowska Bożena, 1979, Teoria literatury w szkole. Z badań nad recepcja liryki, Wrocław.

Chrząstowska Bożena, 2002, Uczę się sam... Program nauczania $w$ liceum ogólnokształcacym, profilowanym i technikum. Język polski w zakresie podstawowym i rozszerzonym, Poznań.

Chrząstowska Bożena, Ciechanowska-Barnuś Joanna, 2015, Dwugłos z życia wzięty, Poznań.

Chrząstowska Bożena, Koc Krzysztof, Nowak Paweł, 2004, Skarbiec języka, literatury, sztuki. Wskazówki metodyczne, Poznań.

Chrząstowska Bożena, Wiegandt Ewa, Wysłouch Seweryna, 1992, 1993, 1997, Literatura współczesna. Podręcznik dla maturzystów, Poznań.

Chrząstowska Bożena, Wysłouch Seweryna, 1978, 1987, 2000, Poetyka stosowana, Warszawa.

Chrząstowska Bożena, Wysłouch Seweryna, 1974, Wiadomości z teorii literatury $w$ analizie literackiej, Warszawa.

Czego Jaś nie przeczyta, tego...,1992, „Gazeta Wyborcza”, nr 224, s. 8-9.

Głowiński Michał, 1997, Lekcja tradycji, lekcja czytania, w: Kompetencje szkolnego polonisty 2. Szkice i artykuły z metodyki z lat 1994-1996, Chrząstowska B. (red.), Warszawa.

Głowiński Michał, 2005, Gang strukturalistów, „Teksty Drugie”, nr 1/2, s. 83-93.

Głowiński Michał, Wołowiec Grzegorz, 2018, Czas nieprzewidziany. Długa rozprawa bez pana, wójta i plebana (rozdz. Bujne życie naukowe), Warszawa.

Jakowska Krystyna, 1992, W obronie podręcznika, „Życie Warszawy”, nr 253, s. 8-9.

Kwiatkowska-Ratajczak Maria, 2021, Docenić szkołę. Dydaktyczna teoria i metodyczna praktyka, Poznań.

Kwiatkowska-Ratajczak Maria (red.), 2011, Innowacje i metody. Tom I. W kregu teorii i praktyki. Podręcznik akademicki dydaktyki kształcenia polonistycznego, Poznań. 
Legeżyńska Anna, 1992, Jaś i Małgosia w rezerwacie, czyli kto się boi „Literatury współczesnej”, „Tygodnik Powszechny”, nr 45, s. 7.

Lewiński Dominik, 2004, Strukturalistyczna wyobraźnia metateoretyczna. O procesach paradygmatyzacji w polskiej nauce o literaturze po 1958 r., Kraków.

Nowak Maria, 1992, Lekcja polskiego piekła, „Gazeta Poznańska”, nr 239, s. 3.

Pieszczachowicz Jan, 1992, Obszar na wpół pustynny. „Literatura współczesna” okrojona, „Polityka”, nr 42, s. 8.

Walc Jan, 1992, MEN da dzieciom... Nowy, pełen głupstw i błędów podręcznik literatury współczesnej, „Życie Warszawy”, nr 237, s. 8-9.

Wit-Kossowska Izabella, 1992, Dzieje bubla. Czy wart 20 tysięcy złotych? „Życie Warszawy", nr 238, s. 9.

Wysłouch Seweryna, 2009, Heroiczne początki. O prof. Bożenie Chrzastowskiej, „Polonistyka”, nr 1, s. 6-9.

Wysłouch Seweryna, 2018, O Bożenie Chrzastowskiej i naszej papierowej „Polonistyce”, w: Polskie czytanie Wschodu. Kultura - autobiografia-edukacja, Kwiatkowska-Ratajczak M., Przymuszała B. (red.), Poznań (lub „Polonistyka. Innowacje" 2018, nr 8, s. 7-14, www.pressto.amu.edu.pl).

\section{O Autorce:}

Seweryna Wysłouch - prof. dr hab.; emerytowany pracownik Instytutu Filologii Polskiej UAM. Autorka prac z zakresu prozy polskiej XX w.: Proza Michała Choromańskiego (1977), Problematyka symultanizmu $w$ prozie (1981), Narracje małe i duże (2015); z dziedziny semiotyki literatury i sztuk plastycznych: Literatura a sztuki wizualne (1994), Literatura i semiotyka (2001); Wyprzedaż semiotyki, pod red. M. Brzóstowicz-Klajn i B. Kaniewskiej (2011). Współautorka napisanej z B. Chrząstowską Poetyki stosowanej $(1978,1987,2000)$ oraz napisanego z B. Chrząstowską i E. Wiegandtową podręcznika dla maturzystów Literatura współczesna (1992, 1993, 1997) i poradnika metodycznego $W$ klasie maturalnej. Ksiażka nauczyciela-polonisty (1999). Zajmowała się także historią polonistyki (udział w zbiorze Stulecie poznańskiej polonistyki, t. I-III (2018-2019)). 